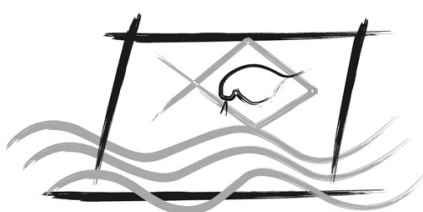

ECOTOX - BRASIL

\title{
Biochemical and genotoxic effects of a commercial formulation of the herbicide tebuthiuron in Oreochromis niloticus of different sizes
}

\author{
M.F. Franco-Bernardes; L.R. Maschio; M.T.V. de Azeredo-Oliveira \& E.A. de Almeida \\ Universidade Estadual Paulista Júlio de Mesquita Filho. Rua Cristóvão Colombo, 2265. 15054-000. \\ São José do Rio Preto, SP. Brazil.
}

(Received April 16, 2014; Accept June 17, 2014)

\begin{abstract}
Pesticides are serious contaminants because they are designed to eliminate pests, but they also affect non-target species. The present study aimed to evaluate the biochemical and genetic effects of the herbicide tebuthiuron in Oreochromis niloticus of different sizes. Thus, we analyzed biomarkers in small and large $O$. niloticus specimens exposed to $62.5,125$ and $250 \mathrm{mg} \mathrm{L}^{-1}$ of tebuthiuron for 72 hours. Fish exposed to $250 \mathrm{mg} \mathrm{L}^{-1}$ had high mortality rates; therefore, the data could not be used. The results showed an increase in EROD activity in fish exposed to $125 \mathrm{mg} \mathrm{L}^{-1}$, but no GST alteration. Antioxidant enzymes GPx and CAT were altered only in the liver of treated fish compared to the control group: CAT decreased in large fish, and GPx increased in small fish. The MDA analysis did not evidence lipid peroxidation. High DNA damage in exposed small fish (not in large fish) was observed using comet assay, but a micronucleus test did not show mutagenicity. Moreover, a comparison between control groups with specimens of different sizes revealed that small fish are more susceptible than large fish to the tebuthiuron effects, since increased comet scores was observed only for smaller fish.
\end{abstract}

Keywords: aquatic toxicology; biomarkers; ecotoxicology; fish; pesticide.

\section{INTRODUCTION}

According to estimates from the Brazilian agency known as UNICA (Sugarcane Industry Union) (Sugarcane Industry Union, 2013), the Center-South region of Brazil will produce 589 million tons of sugarcane during the 2013/2014 harvest. This impressive productivity is supported by the extensive use of several agrochemicals for pest control that, as a consequence, can result in significant negative impacts on the environment. In the case of herbicides alone, more than 30 compounds present in different formulations are used in sugarcane cultivation in Brazil (Martini \& Durigan, 2004), such as 2,4-D, acetochlor, ametryne, clomazone, atrazine, diuron, hexazinone, glyphosate and tebuthiuron, though the toxic effects of some of these compounds on non-target organisms are not known (Oruç \& Üner, 2000; Cattaneo et al., 2008; Xiao et al., 2006; Paiva and Takahashi, 1996; Sikkema \& Shropshire, 2007; Nwani et al., 2011; Akcha et al., 2012; Mei et al., 2012; Lancetõt et al., 2013; Bicalho \& Langenbach,
2013). Tebuthiuron (1-(5-tert-Butyl-1,3,4-thiadiazol-2-yl)1,3 -dimethylurea) is a pre- and post-emergent substituted urea herbicide used for the control of broadleaf and woody weeds, grasses and brush through the inhibition of photosystem II. In Brazil, it is widely used on sugarcane crops (Tofoli et al., 2009), and it is present in different formulations. In some cases, it is present in combination with other herbicides. Tebuthiuron has a long half-life of about one year in soils (Helling, 2005), especially in high-carbon or low-rainfall environments (Chang \& Strizke, 1977), but may have a halflife as low as 20 days under specific conditions (Cerdeira et $a l ., 2007)$. Due to its high water solubility, relatively strong persistence, and low absorption in soil particles, it is expected that tebuthiuron can reach aquatic environments, thus causing negative effects on non-target organisms.

According to data from EPA (2004) and the U.S. National Library of Medicine (2013), tebuthiuron is slightly to practically non-toxic to fish and other aquatic species, with reported 96-hour LC50 values of 87 to $144 \mathrm{mg} \mathrm{L}^{-1}$ in rainbow

*Corresponding author: Eduardo Alves de Almeida; e-mail: ealmeida@ibilce.unesp.br 
trout, and 87 to $112 \mathrm{mg} \mathrm{L}^{-1}$ in bluegill sunfish; however, the sublethal effects of tebuthiuron on fish metabolism are not yet completely known. Due to its intense use in agriculture, especially in sugarcane cultivation in Brazil, any additional information on the sublethal effects of tebuthiuron to fish are important for a better understanding of the risks that this herbicide poses to fish communities that inhabit aquatic environments near agricultural zones. In this context, an assessment of biochemical biomarkers can be useful, since it generally represents the first line of metabolic responses of cells to the contaminants.

The activities of biotransformation enzymes such as cytochrome $\mathrm{P} 450$ isoforms or glutathione S-transferases are commonly evaluated as biomarkers in fish, since they can be significantly induced by several contaminants and therefore indicate a response from the organism to the pollutant (Van Der Oost et al., 2003). Oxidative stress markers, such as the activities of the antioxidant enzymes superoxide dismutase (SOD), glutathione peroxidase (GPx) and catalase (CAT), or the levels of oxidative damage to macromolecules, are also useful biomarkers. Several environmental contaminants can lead cells to increase their rates of oxygen reactive species (ROS) generation due to increases in biotransformation reactions, cyclic redox reactions and/or increases in oxygen uptake by mitochondria for energy production. If not counteracted by antioxidant defense systems, ROS can oxidize macromolecules, thus leading to oxidative damages to proteins, lipids and nucleic acids and generating oxidative stress (Oruç \& Üner 2000; Van Der Oost et al., 2003). Furthermore, the genotoxic effects of environmental pollutants can be monitored using a broad range of assays, such as the micronucleus test and the comet assay (Çavas \& Könen, 2007).

Although numerous studies exist in the literature that report oxidative stress and genotoxic effects caused by different photosystem inhibitor herbicides (i.e. diuron, atrazine and paraquat) in fish, there is no such data available regarding the effects of tebuthiuron. Due to both the intense use of tebuthiuron formulations in sugarcane cultivation in Brazil and the lack of studies regarding the sublethal effects of this herbicide in fish, this work considered whether tebuthiuron affects some classic biochemical biomarkers in Nile Tilapia (Oreochromis niloticus): the phase I enzyme ethoxyresorufinO-deetilase (EROD, indicative of CYP1A), the phase II enzyme glutathione S-transferase (GST), the antioxidant enzymes SOD, CAT and GPx, the levels of oxidative damage to lipids (lipid peroxidation, as malondialdehyde levels, MDA), and levels of genotoxic markers (micronucleous tests, comet assay and nuclear abnormality levels).

Because biomarker responses can vary significantly according to the size of the fish (Peixoto \& Santos, 2009), a factor that can indicate differences in the organism's susceptibility to the pollutant, we were also interested in evaluating the discrepancies in biomarker responses among fish of the same species (O. niloticus) but with significant differences in body length and weight. The sizes of aquatic animals have been shown to play an important role in tissue pollutant loads. Recently Kanak et al. (2014) showed that younger tilapias were affected from metal exposure much more than large ones (two fold in length and five fold in weight), as their antioxidant parameters significantly decreased even in controls. Therefore, although EPA reported low toxicity of tebuthiuron to fish, we hypothesize that this herbicide can poses important metabolic alterations in tilapias, which can be helpful to understand its effects in fish, and that smaller fish are more susceptible to the tebuthiuron effects than larger ones.

\section{MATERIAL AND METHODS}

\section{Chemicals}

All reagents were purchased from Sigma Chemical. In our study, the herbicide was tested as the complex commercial mixture because this is the form in which it is routinely applied in agriculture and introduced into the environment. The commercial preparations of 1-(5-tert-butyl-1,3,4-thiadiazol2-yl)-1,3-dimethylurea (tebuthiuron) (known as Combine* $500 \mathrm{SC})$ was used. It is composed of the herbicide $(50 \% \mathrm{w} / \mathrm{v}$, or $500 \mathrm{~g} / \mathrm{L})$ and inert ingredients $(63.3 \% \mathrm{w} / \mathrm{v}$, or $633 \mathrm{~g} / \mathrm{L})$.

\section{Animals and experimental design}

Adult nile tilapia (O. niloticus) of both sexes were obtained from the Aquaculture Center of Universidade Estadual Paulista, Jaboticabal Campus, and transferred to the Laboratory of Animal Ecology, at Universidade Estadual Paulista, Campus of São José do Rio Preto. The specimens were kept in tanks with clean tap water for at least one week before the experiment. A total of 48 animals were used; 24 were small fish (mean length $11.68 \pm 1.23 \mathrm{~cm}$, mean weight $47.19 \pm 15.5 \mathrm{~g}$ ) and 24 were large fish (mean length $20.74 \pm 1.79 \mathrm{~cm}$, mean weight $284.16 \pm 77.95 \mathrm{~g}$ ).

Fish were placed individually into 48 aquariums of $17 \mathrm{~L}$ in eight groups of six fish each ( $\mathrm{N}=6$, real replicas). Male and female was not separated. For each fish size, the animals were divided into four groups of six animals: the control group and three groups with different concentrations of the herbicide. The nominal concentrations of tebuthiuron that were used were $62.5,125$ and $250 \mathrm{mg} \mathrm{L}^{-1}$ (corresponding to $0.125,0.25$ and $0.500 \mathrm{~mL} \mathrm{~L}^{-1}$ of the commercial Combine $* 500 \mathrm{SC}$ ). Due to the lack of studies regarding subcellular effects of tebuthiuron on fish, and due to the reported low toxicity of this herbicide in fish according to the EPA pesticide database, we chose to test concentrations near the LC50 values reported for rainbow trout $\left(143 \mathrm{mg} \mathrm{L}^{-1}\right)$ and bluegill sunfish $\left(106 \mathrm{mg} \mathrm{L}^{-1}\right)$. Because we used a formulation of tebuthiuron instead of the pure standard, we also considered the LC50 values reported by EPA for formulated tebuthiuron products (20 to 80\%) for fathead minnow $\left(>180 \mathrm{mg} \mathrm{L}^{-1}\right)$. We also considered the fact that the fish in our study were exposed to the formulated tebuthiuron for only $72 \mathrm{~h}$. According to the EPA pesticide 
database, chronic exposure (45 days) of rainbow trout to 52 $\mathrm{mg} \mathrm{L}^{-1}$ of tebuthiuron caused no mortality, but only effects on growth. This further justifies the elevated concentrations used in our study.

The aquariums were kept under constant aeration and temperature. No food was supplied to the fish during the experiment, and the animals were exposed to the herbicide for $72 \mathrm{~h}$. After this period, they were anesthetized with benzocaine for removal of the liver, gills and blood. The liver and gills were frozen at $-80^{\circ} \mathrm{C}$ for subsequent biochemical analysis. The blood was used for micronucleus tests and comet assays on the same day.

\section{Preparation of samples for Biochemical analysis}

For the analysis of enzymes EROD, GST, SOD, GPx and CAT, tissues (liver and gills) were homogenized (1:4, w:v) in Tris- $\mathrm{HCl} 20 \mathrm{mM}, \mathrm{pH} 7.5$ containing $0.5 \mathrm{M}$ of sucrose, $1 \mathrm{mM}$ of etylenediamine tetraacetic acid (EDTA), $1 \mathrm{mM}$ of dithiothreitol (DTT), and $0.15 \mathrm{M}$ of $\mathrm{KCl}$ containing $1 \mathrm{mM}$ of the protease inhibitor phenylmethylsulfonyl fluoride (PMSF). The homogenate was centrifuged at $10,000 \mathrm{~g}$ for 30 $\min$ at $4^{\circ} \mathrm{C}$, and the resulting supernatants were centrifuged at $50,000 \mathrm{~g}$ for $60 \mathrm{~min}$ at $4^{\circ} \mathrm{C}$. The supernatant obtained after this second centrifugation was used for the analyses of GST, SOD, GPx and CAT, and the pellet of the liver samples was re-suspended in $100 \mathrm{ml}$ of $0.1-\mathrm{M}$ Tris- $\mathrm{HCl}, \mathrm{pH} 7.5$, containing $1 \mathrm{mM}$ of EDTA, $1 \mathrm{mM}$ of DTT, and $0.1 \mathrm{M}$ of $\mathrm{KCl}$ and used to analyze EROD activity. The prepared samples were aliquoted for later analysis. For the lipid peroxidation analysis, tissues (liver and gills) were homogenized (1:3 weight: volume) in $0.1 \mathrm{M}$ of Tris $\mathrm{HCl}, \mathrm{pH} 8.0$. Prepared samples were analyzed on the same day.

\section{BIOCHEMICAL ANALYSIS}

\section{EROD, GST, SOD, GPX and CAT}

The EROD assay measures the 0-dealkylation, mediated by CYP1A, of non-fluorescent substrate 7-ethoxy-resorufin in resorufin, a fluorescent product detected by fluorimeter $(\lambda$ excit $=537 \mathrm{~nm}$ גemiss $=583 \mathrm{~nm}$ ) (Sarasquete and Segner, 2000). The assay mixture contained $80 \mathrm{mM}$ of potassium phosphate buffer (pH 7.4), $335 \mathrm{lM}$ 7-ethoxyresorufin, $20 \mathrm{mM}$ of NADPH, and microsomal liver extract (prepared sample). The reaction was observed for $3 \mathrm{~min}$ at $30^{\circ} \mathrm{C}$. EROD activity $\left(\mathrm{pmol} \mathrm{min} \mathrm{m}^{-1}\right.$ $\mathrm{mg}^{-1}$ of protein) was calculated based on a previously prepared resorufin standard curve.

GST activity was evaluated according to Keen et al. (1976). The assay mixture contained $0.2 \mathrm{M}$ of potassium phosphate buffer, $\mathrm{pH} \mathrm{6.5,} \mathrm{the} \mathrm{substrate} \mathrm{1-chloro-2,4-dinitrobenzene}$ (CDNB), GSH, and the sample containing GST. The activity was determined by measuring the increase in absorbance at $340 \mathrm{~nm}$.

The method for analyzing SOD uses a system of superoxide (xanthine / xanthine oxidase) generation coupled with cytochrome $\mathrm{c}$ reduction by the superoxide anion radical, which causes an increase in absorbance at $550 \mathrm{~nm}$ at $25^{\circ}$ C. The addition of the sample containing SOD promotes an inhibition of cytochrome c reduction, because the enzyme competes with cytochrome c by superoxide (Mccord \& Fridovich, 1969).

GPx activity was evaluated according to Sies et al. (1979). In the analysis, the consumption of NADPH was monitored at $340 \mathrm{~nm}$. NADPH is used by glutathione reductase (GR) for the reduction of glutathione, which had been previously oxidized by GPx in the conversion of t-butyl hydroperoxide in its corresponding alcohol.

CAT activity was measured following the method reported by Beutler (1975), in which the rate of decomposition of hydrogen peroxide by the enzyme is quantified through the decrease in absorbance at $240 \mathrm{~nm}$ at $30^{\circ} \mathrm{C}$.

Protein levels were measured following the method of Bradford (1976). In a microtube, the Bradford reagent and the sample were combined. After $40 \mathrm{~min}$ in the dark, the samples were measured in a spectrophotometer at $595 \mathrm{~nm}$. The protein concentration was calculated using the calibration curve prepared from bovine serum albumin (BSA) and the Bradford reagent.

\section{Lipid peroxidation}

Lipid peroxidation levels were determined by measuring the product formed from the combination of malondialdehyde, and thiobarbituric acid (TBA) through High Performance Liquid Chromatography (HPLC) and UV/Vis detection. After homogenizing the sample, the TBA was dissolved in $0.2 \mathrm{M}$ of $\mathrm{HCl}$ and the solution was added to the sample. The reaction mixture was then heated at $90{ }^{\circ} \mathrm{C}$ for $60 \mathrm{~min}$. The colored derivative was extracted with butanol and quantified using HPLC at $532 \mathrm{~nm}$, in terms of a malondialdehyde (MDA) standard calibration curve that had been previously prepared using the same procedure used for the samples. The HPLC system consisted of an ESA584 pump and an ESA526 UV/ Vis detector. The column used was an ACE 5 C18 (250_x 4.6 $\mathrm{mm}, 5 \mu \mathrm{m})$. Chromatogram monitoring and peak identification and quantification were performed using the EZChrom Elite software (Agilent Technologies). The mobile phase was 0.05 $\mathrm{M}$ of $\mathrm{KH}_{2} \mathrm{PO}_{4}, \mathrm{pH} 7.0$, with $40 \%$ methanol, and was pumped at an isocratic flow of $1 \mathrm{~mL} \mathrm{~min}{ }^{-1}$.

\section{GENOTOXIC EFFECTS}

\section{Micronucleus test}

In the micronucleus test (Al Sabti, 1986; Al Sabti and Metcalfe, 1995), a cardiac puncture was performed to remove $3 \mathrm{cc}$ of blood from each animal. The smear technique was used to prepare three slides for each fish. The material was fixed in absolute methanol and stained through a Feulgen reaction. A total of 1000 erythrocytes were analyzed in each slide, totaling 
3000 erythrocytes per fish. This analysis was performed with an optical microscope under $100 \mathrm{x}$ magnification, and the frequency of micronuclei in treated animals was compared to the negative control. The frequencies of nuclear abnormalities (notched, lobed, broken eggs and bebbled, as described by Carrasco 1990), was also determined. No positive control was used. Since all cells in the field of vision are counted, the total number of cells analyzed per animal can vary. Thus, the total number of cells counted was transformed into percentage values. Therefore, the frequency is measured as a percentage.

\section{Comet assay}

The comet assay was performed followed the method described by Singh et al. (1988). Blood samples were each diluted in $1000 \mu \mathrm{l}$ of saline solution. Slides were made with $10 \mathrm{uL}$ of this cell suspension and $120 \mu \mathrm{l}$ of low melting point agarose $(0.5 \%)$ at $37{ }^{\circ} \mathrm{C}$. The slides remained in a lysis solution ( $1 \mathrm{~mL}$ of Triton X-100, $10 \mathrm{~mL}$ of DMSO and $89 \mathrm{~mL}$ of lysing solution stock, $\mathrm{pH} 10.0$ - stock solution: $2.5 \mathrm{M}$ of $\mathrm{NaCl}, 100 \mathrm{mM}$ of EDTA100, $10 \mathrm{mM}$ to $1 \mathrm{~L}$ of Tris) in the refrigerator for one hour. After their time in the lysis solution, the slides were placed inside a horizontal electrophoresis system for 20 minutes at $25 \mathrm{~V}, 300 \mathrm{~mA}$. The slides were neutralized with $0.4 \mathrm{M}$ of Tris ( $\mathrm{pH} 7.5$ ), for 15 minutes and fixed in ethanol for 10 minutes. Cells with no DNA damage migrate homogeneously, while cells with damaged DNA form fragments of different sizes, and the smaller ones migrate faster during electrophoresis, thus forming the tail of a comet.

From each fish, two slides were prepared. On each slide, 50 nucleoides were analyzed. The slides were stained with ethidium bromide $\left(0.002 \mathrm{mg} \mathrm{mL}^{-1}\right)$. The analysis was performed with a fluorescence microscope, filter B - 34 (excitation: $\lambda=420-490 \mathrm{~nm}$, barrier $\lambda=520 \mathrm{~nm}$ ) under 40 $\mathrm{x}$ magnification. The comets were classified according to the comet length using the visual parameters proposed by Kobayashi et al. (1995): class 0 (no damage), class 1 (slight damage); class 2 (moderate damage), class 3 (major damage). The injury score was calculated by multiplying the total number of cells in each class by class value $(0-3)$. No positive control was used.

\section{Statistical analysis}

To verify the effect of the herbicide on the animals, the treatments were compared to the control. The small fish group was analyzed separately from the large fish group. Tests for normality (Shapiro-Wilk) and homogeneity of variances (Levene) were applied. For the parametric data, the oneway ANOVA was used, followed by the Tukey test. For nonparametric data, the Kruskal-Wallis test was used, followed by multiple comparisons of mean ranks.

To see whether the size of the fish influences the effect of the biomarkers studied, the differences between small and large fish and their respective control groups were calculated. For the parametric data, the Student T-test was used, and for non-parametric data, the Mann-Whitney test was used. Significant differences were accepted only when $p<0.05$. Analyses were performed with the Statistica 7.0 software.

\section{RESULTS}

\section{Mortality}

During the exposure period, a high mortality rate of the animals was observed in aquariums containing $250 \mathrm{mg} \mathrm{L}^{-1}$ of tebuthiuron. In aquariums containing small fish, four of them died, leaving only two animals to be analyzed. In aquariums containing large fish, two of them died, leaving four for analysis. Due to this mortality rate, statistical analyses were infeasible with the group of fish exposed to the high concentration of the herbicide, and for this reason, data for the fish exposed to 250 $\mathrm{mg} \mathrm{L}^{-1}$ of the herbicide were not considered any further. None of the fish died in the other treatments.

\section{Biotransformation enzymes}

The results regarding EROD and GST activities are shown in Figure 1. EROD activity was measured only in the liver, due to a lack of gill samples available for measurement. The activity of the enzyme increased in small and large fish exposed to $125 \mathrm{mg} \mathrm{L}^{-1}$ when compared to their respective controls. The analysis did not show significant difference between animals of different sizes. With respect to GST activity, no differences were observed between the treated groups and the respective control groups in neither the liver nor the gills from fish of either size. When the GST activity of fish of different sizes was compared, it was noted that GST activity in the liver was higher in large fish than in small fish, but no such difference was observed in the gills.

\section{Oxidative stress parameters}

Oxidative stress parameters (SOD, CAT, and GPx activities, and MDA levels) measured in fish from the exposure experiment are shown in Figure 2. The hepatic SOD activity showed no significant differences in small and large fish treated with tebuthiuron in comparison to their respective control groups. The analysis also showed no significant differences between $O$. niloticus of different sizes. The SOD activity in the gills did not differ significantly in exposed groups when compared to their controls; however, the enzyme activity was higher in large fish than in small fish.

GPx activity was significantly higher in the liver of small fish exposed to $125 \mathrm{mg} \mathrm{L}^{-1}$ than in the control group, though no significant difference was found in large fish treated with the herbicide when compared to their control group. No difference was observed in GPx activity among animals with different sizes. In the gills, the GPx activity did not differ between treated and control fish in either large or small fish groups, nor when large and small fish were compared. 

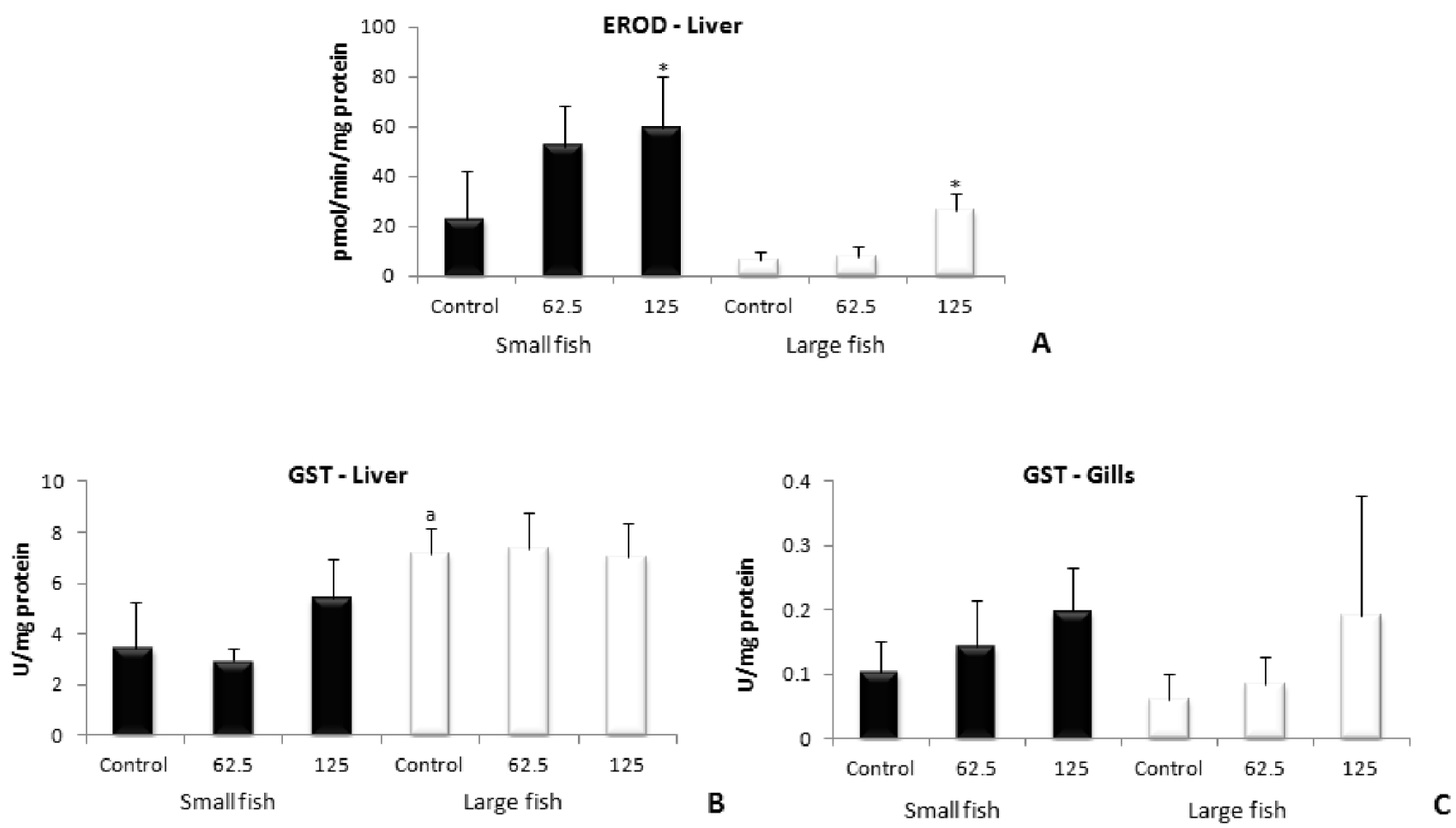

Figure 1 - Activity of biotransformation enzymes EROD in liver (A) and GST in liver (B) and gills (C) of small and large O. niloticus exposed to tebuthiuron for $72 \mathrm{~h}$ at concentrations of 62.5 and $125 \mathrm{mg} \mathrm{L}^{-1}$. *: Significant difference compared to the respective control group; a: Significant difference compared to the smaller control group.

In the liver, the CAT activity did not differ significantly in small $O$. niloticus exposed to herbicide when compared to the control. However, large fish treated with $62.5 \mathrm{mg} \mathrm{L}^{-1}$ had lower CAT activity than the control group. There was no significant difference between the control groups of large or small animals. The CAT activity of the gills did not differ significantly in exposed groups compared with their controls, nor was there any significant difference between fish of different sizes.

No significant difference was observed in MDA levels in livers of fish exposed to the herbicide compared to the control groups. However, large O. niloticus showed a higher level of lipid peroxidation than small specimens. The MDA levels in the gills remained unchanged when treated and control animals were compared. There was also no significant difference between the lipid peroxidation levels in animals of different sizes.

\section{Genotoxic markers}

The micronucleous frequency in erythrocytes from $O$. niloticus specimens of both sizes exposed to tebuthiuron did not differ from their respective controls (Fig. 3). On the other hand, large fish had lower micronucleous frequency than small fish. Some nuclear abnormalities were also observed, being the notched the most predominant, but no differences were observed between treated and control groups. The nuclear abnormalities did not differ between small and large fish, either. The comet assay showed that small fish exposed to 125 mg L $\mathrm{L}^{-1}$ of the herbicide presented a higher level of damaged erythrocytes than the control group. Furthermore, the analysis revealed that large fish had a higher comet score than small fish.

\section{DISCUSSION}

Although studies regarding the biological effects of pesticides have increased substantially over the last few years, there are no studies on the effects of tebuthiuron on biochemical biomarker in fish. For this reason, the present work brings important information about the susceptibility and responses of fish to a commercial formulation of this herbicide, which has been extensively used in sugarcane agriculture in Brazil. EROD activity was higher in the group of large fish exposed to $125 \mathrm{mg} \mathrm{L}^{-1}$ of the tebuthiuron formulation when compared to the controls. Numerous field studies have demonstrated a significant increase in hepatic CYP1A activity in many species of fish from polluted environments, though no studies exist regarding the effects of tebuthiuron on this enzyme. Nevertheless, Schoket \& Vincze (1990) observed a significant increase in EROD activity in rats intragastrically treated with diuron $(0.73,1.62,2.43$ and $3.65 \mathrm{mmol} / \mathrm{kg})$ and chlorotoluron $(2.35,5.22,7.83$ and $11.74 \mathrm{mmol} / \mathrm{Kg})$, both phenylurea herbicides, for 3 days. As demonstrated in this study, the herbicide tebuthiuron was also able to induce EROD activity in tilapia, an increase that was not followed by the phase II enzyme GST. This result suggests that GST is not involved in the metabolism of tebuthiuron. Morton \& Hoffman (1976) reported that the main tebuthiuron metabolite excreted by 

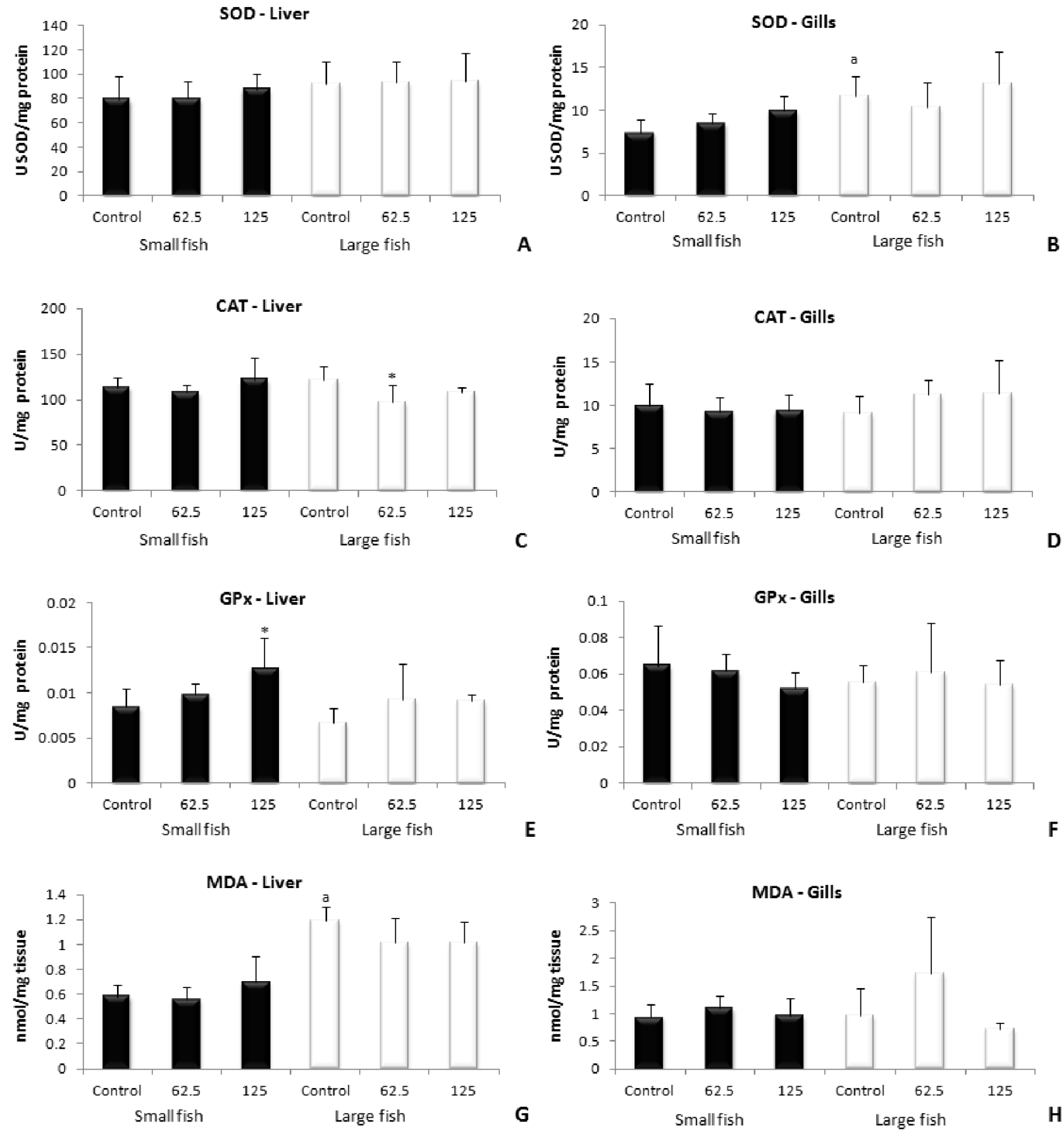

Figure 2 - Oxidative stress parameters: SOD in liver (A) and gills (B), CAT in liver (C) and gills (D), GPx in liver (E) and gills (F) and MDA in liver (A) and gills (B) of small and large $O$. niloticus exposed to tebuthiuronfor $72 \mathrm{~h}$ at concentrations of 62.5 and $125 \mathrm{mg} \mathrm{L}^{-1}$. *: Significant difference compared to the respective control group; a: Significant difference compared to the smaller control group.

fish is formed by $\mathrm{N}$-demethylation of the substituted urea side chain; but in our work, no conjugated compounds were found, which is consistent with EROD induction and the lack of GST effects on tilapias. Interestingly, neither EROD nor GST activities varied according to the size of the fish, and both large and small fish presented similar responses to the pesticide exposure in terms of these enzymes.

SOD activity did not vary in treated fish of either size compared to their controls, in the liver nor in the gills. This result indicates that elevated levels of anion radical are not being formed because of tebuthiuron exposure, which is consistent with the lack of increase in MDA levels. Nevertheless, the GPx activity was higher in the livers of small $O$. niloticus specimens exposed to $125 \mathrm{mg} \mathrm{L}^{-1}$ of tebuthiuron, which may indicate the production of reactive intermediates as a result of tebuthiuron exposure. Even though a small but significant decrease in CAT activity in the liver of large fish exposed to the lower concentration of the herbicide formulation could increase the susceptibility of fish to oxidative stress, the increase in GPx activity can also be considered to be a protective 

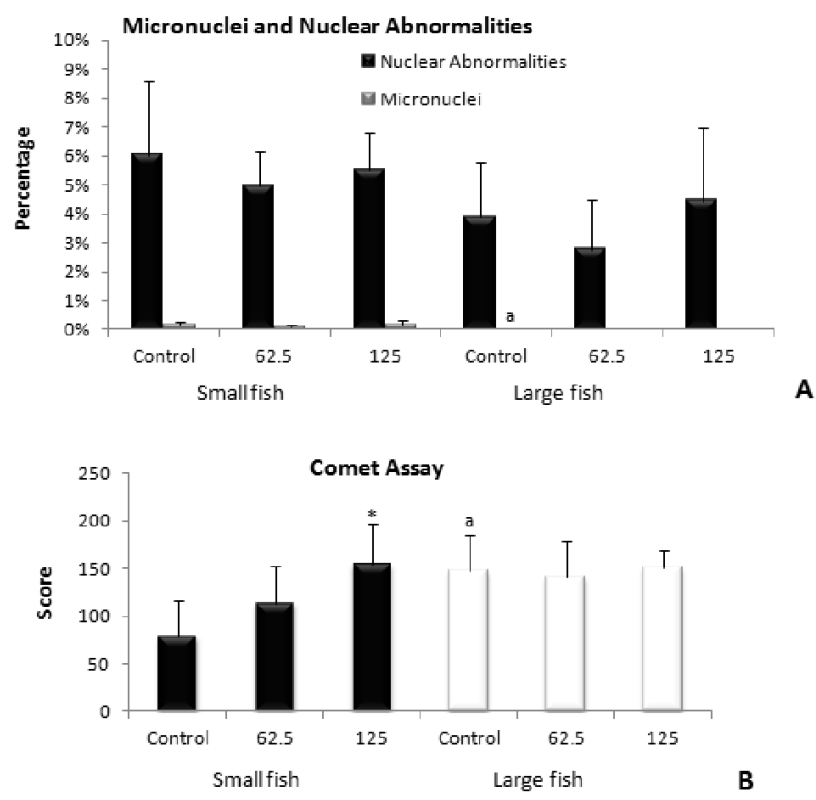

Figure 3 - Genotoxic markers: Micronuclei, Nuclear Abnormalities (A) and Comet Assay (B) in erythrocytes of and large O. niloticus exposed to tebuthiuron for $72 \mathrm{~h}$ at concentrations of 62.5 and $125 \mathrm{mg} \mathrm{L}^{-1}$. *: Significant difference compared to the respective control group; $\mathbf{a}$ : Significant difference compared to the smaller control group.

response of hepatocytes against ROS. This response would explain the lack of increases in lipid peroxidation levels. No studies were found regarding MDA levels in fish exposed to photosynthesis inhibitor herbicides, but an investigation with male Wistar rats exposed to atrazine $(300 \mathrm{mg} / \mathrm{kg})$ through gavage for 7, 14 and 21 days showed a significant increase in hepatic lipid peroxidation (Singh et al., 2011). It is likely that the concentrations of herbicide used in the present study were not enough to generate oxidative stress. Nevertheless, it should be mentioned that the concentrations used herein were very high, and were close to both the concentrations that are recommended for agricultural use and to the LC50 values reported for other fish species. In any case, these concentrations are not expected to be found in natural aquatic environments. According to data from the EPA, tebuthiuron was found in several surface water samples from the U.S. in the ' 80 s and '90s at levels of 1 to $200 \mathrm{ng} \mathrm{L}^{-1}$ (Stavola, 2013) much lower than the concentrations used in the present study. Therefore, considering the fact that there was no evidence of oxidative stress in fish in the present study, we can suppose that tebuthiuron is not able to generate oxidative stress in fish at environmentally relevant concentrations, after the duration of exposure used in the present work.

With respect to DNA damage, our results also showed no difference in the frequency of micronuclei and nuclear abnormalities in treated animals compared to the control, which indicates that tebuthiuron poses no potential genotoxic effects on fish, as previously reported by the EPA. However, small fish exposed to $125 \mathrm{mg} \mathrm{L}^{-1}$ had a higher comet score than the control. This data shows that, in the concentrations tested, tebuthiuron may cause DNA damage, though likely not at realistic environmental concentrations. Again, more studies are necessary to verify the genotoxic effects after longer exposure periods. Indeed, the presence of increased comet scores without increases in micronucleous levels suggests that the herbicide caused genotoxicity, but not mutagenicity. In a study with atrazine in erythrocytes of Channa punctatus, Nwani et al. (2011) observed an increase in micronuclei and an increase in DNA damage in treated animals through comet assay, results which are consistent with our findings.

Comparisons were also made between biomarker responses in fish of different sizes. In general, larger tilapias presented higher GST activity in the liver and higher SOD activity in the gills, results which are consistent with higher levels of MDA. Similarly, DNA damage levels measured by the comet assay were higher in larger fish. Smaller fish, on the other hand, presented higher micronuclei frequencies than larger fish. This data suggests that larger fish may be more susceptible to lipid peroxidation and DNA damage, and they therefore possess higher activities of protective enzymes, such as SOD and GST. Higher GST activity and EROD induction may also indicate that larger fish present a better biotransformation response to tebuthiuron compared to smaller fish. In addition, the higher micronucleous frequency in small fish compared to large fish can indicates that larger fish also present better DNA repair mechanisms than smaller fish. All of this data indicates that small fish could be more susceptible to tebuthiuron exposure than large fish, as hypothesized. Small fish were also more responsive than large fish in terms of the number of biomarkers that responded to the herbicide exposure. EROD increased in both small and large fish exposed to the $125 \mathrm{mg} \mathrm{L}^{-1}$ concentration. In fact, in the case of large fish, this was the only alteration observed among the biomarkers tested. In small fish, in addition to EROD induction, a decrease in CAT activity, an increase in GPx activity, and an increase in comet score were also observed. Larger fish, with larger body mass and larger organs, such as the liver, have more bioaccumulation and biotransformation capacity compared to smaller fish, which can explains these differences. Nevertheless, it is also known that the metabolic activity of a young individual is normally higher than the older individual (Kanak et al., 2014), so the most frequent variations observed in biomarkers from smaller fish compared to large fish could be also due to a better response capacity in smaller fish, an hypothesis that remains to be clarified. Indeed, it should be considered that both experiments with small and large fish were done in a aquariums with the same water volume, so both small and large fish received the same amount of the herbicides that, proportionally to the fish size, implies that there was more thebutiuron available in water to small fish than to larger ones, which can also account for the increased biomarker responses in smaller fish.

\section{CONCLUSIONS}

In conclusion, this study shows that, at the concentrations and exposure duration tested, tebuthiuron can increase the fase I biotransformation enzymes in fish of both sizes, and 
can increase the production of reactive intermediates and generate genotoxicity in small fish. Larger fish seem to be less susceptible to the effects of tebuthiuron compared to smaller fish, which were more responsive, a result that agrees with a study recently published in this same journal by Kanak et al. (2014), in which small tilapias were more susceptible to metal effects compared to larger ones.

\section{ACKNOWLEDGMENTS}

The authors would like to thank the Brazilian foundation "Fundação de Amparo à Pesquisa do Estado de São Paulo FAPESP" (2010/04028-9) for their financial support for this project.

\section{REFERENCES}

AKCHA, F., SPAGNOL, C. \& ROUXEL, J. 2012. Genotoxicity of diuron and glyphosate in oyster spermatozoa and embryos. Aquat Toxicol, 106-107: 104- 113. http://dx.doi.org/10.1016/j. aquatox.2011.10.018

A1-SABTI, K. 1986. Comparative micronucleated erythrocyte cell induction in three cyprinids by five carcinogenic-mutagenic chemicals, Cytobios, 47: 147-154.

AL-SABTI, K. \& METCALFE, C.D. 1995. Fish micronuclei for assessing genotoxicity in water. Mutat Res, 343: 121-135. http:// dx.doi.org/10.1016/0165-1218(95)90078-0

BEUTLER, E. 1975. Red Cell Metabolism: A Manual of Biochemical Methods. New York.

BICALHO, S. T. T. \& LANGENBACH, T. 2013. The fate of tebuthiuron in microcosm with riparian forest seedlings. Geoderma, 207-208: 66-70. http://dx.doi.org/10.1016/j. geoderma.2013.04.032

BRADFORD, M. M. 1976. A rapid and sensitive method for the quantitation of microgram quantities of protein utilising the principle of proteindye binding assay. Anal Biochem, 72: 248254. http://dx.doi.org/10.1016/0003-2697(76)90527-3

CARRASCO, K. R., TILBURY, K. L. \& MYERS, M. S. 1990. An assessment

of the piscine micronuclei test as an in situ biological indicator of chemical contaminant effects, Can J Fish Aquat Sci, 47: 21232136. http://dx.doi.org/10.1139/f90-237

CATTANEO, R., LORO, V. L., SPANEVELLO, R., SILVEIRA, F. A., LUZ, L., MIRON, D. S. \& FONSECA, M. B. 2008. Metabolic and histological parameters of silver catfish (Rhamdia quelen) exposed to commercial formulation of 2,4-dichlorophenoxiacetic acid (2,4-D) herbicide. Pest Biochem Physiol, 92: 133-137. http://dx.doi.org/10.1016/j.pestbp.2008.07.004

ÇAVAS, T. \& KÖNEN, S. 2007. Detection of cytogenetic and DNA damage in peripheral erythrocytes of goldfish (Carassius auratus) exposed to a glyphosate formulation using the micronucleus test and the comet assay. Mutagenesis, 22: 263-268. http://dx.doi. org/10.1093/mutage/gem012

CERDEIRA, A. L., DESOUZA, M. D., QUEIROZ, S. C., FERRACINI, V. L., BOLONHEZI, D., GOMES, M. A, ROSA, M. A., BALDERRAMA, O., RAMPAZZO, P., QUEIROZ, R. H., NETO, F. C. \& MATALLO, M. B. 2007. Leaching and halflife of the herbicide tebuthiuron on a recharge area of Guarany aquifer in sugarcane fields in Brazil. J Environ Sci Health, 42: 635-9. http://dx.doi.org/10.1080/03601230701465593

CHANG, S. S. \& STRIZKE, J. F. 1977. Sorption, movement, and dissipation of tebuthiuron in soils. Weed Sci, 25: 184-187.

EPA (Environmental Protection Agency). 2004. Tebuthiuron analysis of risks to endangered and threatened pacific salmon and steelhead. http://www.epa.gov/espp/litstatus/effects/tebuthiuron/ tebuthiuron_analysis.pdf. Accessed 25 september 2013.

HELLING, C. S. 2005. "The science of soil residual herbicides," in: Soil Residual Herbicides: Science and Management, ed. R. C. Van Acker (Topics in Canadian Weed Science, Saint-Anne-deBellevue, Quebec: Canadian Weed Science Society), 3 - 22.

KANAK, E. G., DOGAN, Z., EROGLU, A., ATLI, G. \& CANLI, M. 2014. in press. Effects of fish size on the response of antioxidant systems of Oreochromis niloticus following metal exposures. Fish Physiol Biochem. http://dx.doi.org/10.1007/s10695-0149907-x

KEEN, J. H., HABIG, W. H. \& JAKOBY, W. B. 1976. Mechanism for the several activities of the glutathione S-transferases. J Biol Chem, 251: 6183-8. http://www.jbc.org/content/251/20/6183

KOBAYASHI, H., SUGIYAMA, C., MORIKAMA, Y., HAYASHI, M. \& SOFUNI, T. 1995. A comparison between manual microscopic analysis and computerized image analysis in the cell gel electrophoresis. MMS Commun, 3: 103-115.

LANCETÕT, C., ROBERTSON, C., NAVARRO-MARTÍN, L., EDGE, C., MELVIN, S. D., HOULAHAN, J. \& TRUDEAU, V. L. 2013. Effects of the glyphosate-based herbicide RoundupWeatherMax ${ }^{\circledR}$ on metamorphosis of wood frogs (Lithobates sylvaticus) in natural wetlands. Aquat Toxicol, 140141: 48-57. http://dx.doi.org/10.1016/j.aquatox.2013.05.012

MARTINI, G. \& DURIGAN, J. C. 2004. Influência do teor de água na superfície do solo sobre a eficácia e seletividade do flazasulfuron, na cultura de cana-de-açúcar. Planta Daninha, 22: 259-267. http://dx.doi.org/10.1590/S0100-83582004000200013

MCCORD, J. M. \& FRIDOVICH, I. 1969. Superoxide dismutase. An enzymic function for erythrocuprein (hemocuprein), J Biol Chem, 224: 6049-55. http://www.jbc.org/content/244/22/6049

MEI, M., DU, Z., XU, R., CHEN, Y., ZHANG, H. \& QU, S. 2012. Photocatalytic degradation of hexazinone and its determination in water via UPLC-MS/MS. J Hazard Mater, 221-222: 100-108. http://dx.doi.org/10.1016/j.jhazmat.2012.04.018

MORTON, D. M. \& HOFFMAN, D. G. 1976. Metabolism of a new herbicide, tebuthiuron \{1-[5-(1,1-dimethylethyl)-1,3,4thiadiazol-2-yl]-1, 3-dimethylurea $\}$, in mouse, rat, rabbit, dog, duck, and fish. J Toxicol Environ Health, 1: 757-768. http:// dx.doi.org/10.1080/15287397609529374

NWANI, C. D., NAGPURE, N. S., KUMAR, R., KUSHWAHA, B., KUMAR, P. \& LKRA, W. S. 2011. Mutagenic and genotoxic assessment of atrazine-based herbicide to freshwater fish Channa punctatus (Bloch) using micronucleus test and single cell gel electrophoresis. Environ Toxicol Pharmacol, 31: 314-322. http:// dx.doi.org/10.1016/j.etap.2010.12.001

ORUÇ, E. Ö. \& ÜNER, N. 2000. Combined effects of 2,4-D and azinphosmethyl on antioxidant enzymes and lipid peroxidation in liver of Oreochromis niloticus. Comp Biochem Physiol C. 127: 291-296. http://dx.doi.org/10.1016/S0742-8413(00)001596

PAIVA, W. J. M. \& TAKAHASHI, C. S. 1996. Evaluation of mutagenic potential of the active principle of the herbicide Ametrine in in vivo and in vitro systems. Braz J Genet, 19: 6571. http://www.gmb.org.br/Revistas/V19/v19a009.pdf

PEIXOTO, F. P., SANTOS, D. L., VILELA, S. \& FONTAÍNHASFERNANDES, A. 2009. Caracterização da mitocôndria isolada de fígado de tilápia-do-nilo (Oreochromis niloticus) e alterações da bioenergética mitocondrial causadas pela exposição ao herbicida oxifluorfena. Arq Bras Med Vet Zoot, 61: 386-392. http://dx.doi.org/10.1590/S0102-09352009000200015 
SARASQUETE, C. \& SEGNER, H. 2000. Cytochrome P4501A (CYP1A) in teleostean fishes. A review of immunohistochemical studies. Sci of Total Environ, 247: 313-32. http://dx.doi. org/10.1016/S0048-9697(99)00500-8

SCHOKET, B. \& VINCZE, I. 1990. Dose-related induction of rat hepatic drug metabolizing enzymes by diuron and chlorotoluron, two substituted phenylurea herbicides. Toxicol Lett, 50: 1-7. http://dx.doi.org/10.1016/0378-4274(90)90246-I

SIES, H. et al 1979. Increased biliary glutathione disulfide release in chronically ethanol-treated rats. FEBS Lett, 103: 287-90. http:// dx.doi.org/10.1016/0014-5793(79)81346-0

SIKKEMA, P. H., SHROPSHIRE, C. \& SOLTANI, N. 2007. Effect of clomazone on various market classes of dry beans. Crop Prot, 26: 943-947. http://dx.doi.org/10.1016/j.cropro.2006.08.014

SINGH, N. P., MCCOY, M. T., TICE, R. R. \& SCHNEIDER, L.L. 1988. A simple

technique for quantitation of low levels of DNA damage in individual cells. Exp Cell Res, 175: 184-191. http://dx.doi. org/10.1016/0014-4827(88)90265-0

SINGH, M., SANDHIR, R. \& KIRAN, R. 2011. Effects on antioxidant status of liver following atrazine exposure and its attenuation by vitamin E. Exp Toxicol Pathol, 63: 269-276. http://dx.doi.org/10.1016/j.etp.2010.01.005

STAVOLA A. Tebuthiuron Analysis of Risks to Endangered and Threatened Pacific Salmon and Steelhead. http://www.epa. gov/espp/litstatus/effects/tebuthiuron/tebuthiuron_analysis.pdf. Accessed 30 jul 2013.

Sugarcane Industry Union - UNICA. http://www.unicadata.com.br/. Accessed 30 jul 2013.

TOFOLI, G. R., VELINI, E. D., NEGRISOLI, E., CAVENAGHI, A. L. \& MARTINS, D. 2009. Dinâmica do tebuthiuron em palha de cana-de-açúcar. Planta Daninha, 27: 815-821. http://dx.doi. org/10.1590/S0100-83582009000400020

U.S. National Library of Medicine, Hazardous Substances Databank, Bethesda (MD). http://toxnet.nlm.nih.gov/cgi-bin/sis/search/f?./ temp/ 1xsHYZ:1. Accessed 30 jul 2013.

VAN DER OOST, R., BEYER, J. \& VERMEULEN, N. P. E. 2003. Fish bioaccumulation and biomarkers in environmental risk assessment: a review. Environ Toxicol Pharmacol, 13: 57-149. http://dx.doi.org/10.1016/S1382-6689(02)00126-6

XIAO, N., JING, B., GE, F. \& LIU, X. 2006. The fate of herbicide acetochlor and its toxicity to Eisenia fetida under laboratory conditions. Chemosphere, 62: 1366-1373. http://dx.doi. org/10.1016/j.chemosphere.2005.07.043 